\title{
Synthesis and Compressibility of Novel Nickel Carbide at Pressures of Earth's Outer Core
}

\author{
Timofey Fedotenko ${ }^{1, *}$, Saiana Khandarkhaeva ${ }^{1}$, Leonid Dubrovinsky ${ }^{2}$ (D), Konstantin Glazyrin ${ }^{3}$ (D), \\ Pavel Sedmak ${ }^{4}$ and Natalia Dubrovinskaia ${ }^{1,5}$ (D)
}

1 Material Physics and Technology at Extreme Conditions, Laboratory of Crystallography, University of Bayreuth, D-95440 Bayreuth, Germany; saiana.khandarkhaeva@uni-bayreuth.de (S.K.); natalia.dubrovinskaia@uni-bayreuth.de (N.D.)

2 Bayerisches Geoinstitut, University of Bayreuth, D-95440 Bayreuth, Germany; leonid.dubrovinsky@uni-bayreuth.de

3 Deutsches Elektronen Synchrotron, 22607 Hamburg, Germany; konstantin.glazyrin@desy.de

4 European Synchrotron Radiation Facility, F-38043 Grenoble, France; pavel.sedmak@anton-paar.com

5 Department of Physics, Chemistry and Biology (IFM), Linköping University, SE-581 83 Linköping, Sweden

* Correspondence: timofeyfedotenko@gmail.com

Citation: Fedotenko, T.;

Khandarkhaeva, S.; Dubrovinsky, L.; Glazyrin, K.; Sedmak, P.;

Dubrovinskaia, N. Synthesis and Compressibility of Novel Nickel Carbide at Pressures of Earth's Outer Core. Minerals 2021, 11, 516. https:// doi.org/10.3390/min11050516

Academic Editor: Fumagalli Patrizia

Received: 16 April 2021

Accepted: 10 May 2021

Published: 13 May 2021

Publisher's Note: MDPI stays neutral with regard to jurisdictional claims in published maps and institutional affiliations.

Copyright: (C) 2021 by the authors. Licensee MDPI, Basel, Switzerland. This article is an open access article distributed under the terms and conditions of the Creative Commons Attribution (CC BY) license (https:/ / creativecommons.org/licenses/by/ $4.0 /)$.

\begin{abstract}
We report the high-pressure synthesis and the equation of state (EOS) of a novel nickel carbide $\left(\mathrm{Ni}_{3} \mathrm{C}\right)$. It was synthesized in a diamond anvil cell at 184(5) GPa through a direct reaction of a nickel powder with carbon from the diamond anvils upon heating at $3500(200) \mathrm{K}$. $\mathrm{Ni}_{3} \mathrm{C}$ has the cementite-type structure (Pnma space group, $a=4.519$ (2) $\AA, b=5.801$ (2) $\AA, c=4.009$ (3) $\AA$ ), which was solved and refined based on in-situ synchrotron single-crystal $X$-ray diffraction. The pressurevolume data of $\mathrm{Ni}_{3} \mathrm{C}$ was obtained on decompression at room temperature and fitted to the 3rd order Burch-Murnaghan equation of state with the following parameters: $V_{0}=147.7(8) \AA^{3}, K_{0}=157(10)$ $\mathrm{GPa}$, and $\mathrm{K}_{0}{ }^{\prime}=7.8(6)$. Our results contribute to the understanding of the phase composition and properties of Earth's outer core.
\end{abstract}

Keywords: nickel carbide; high pressures; X-ray diffraction; equation of state; Earth's outer core

\section{Introduction}

Nickel is known as the second most abundant element in Earth's core after iron [1,2]. Cosmochemical models and studies of meteorites suggest that Earth's core apart from Fe contains also about $5 \mathrm{wt} \%$ of $\mathrm{Ni}[3,4]$ and, in the inner core, up to $10 \mathrm{wt} \%$ of light elements [5-7]. Which elements exactly and their amount is a subject of active discussions [3]. A large amount of carbon in iron meteorites [8], its high solubility in liquid Fe at high pressure [5,9], and high abundance in the solar system [5] suggest carbon to be one of the most important light elements in Earth's core. Recent estimations of the inner core composition indicate up to $2.0 \mathrm{wt}$.\% of carbon [3]. All these facts resulted in numerous high-pressure studies of the $\mathrm{Fe}-\mathrm{C}$ system in recent decades. The intermediate $\mathrm{Fe}-\mathrm{C}$ compounds $\mathrm{Fe}_{3} \mathrm{C}$ and $\mathrm{Fe}_{7} \mathrm{C}_{3}$ were suggested to be the most likely candidates to the carbon-bearing phases in Earth's core, as they were found at relevant pressures and temperatures [2,5,10-12]. Although at room temperature $\mathrm{Fe}_{3} \mathrm{C}$ was shown to be stable up to $187 \mathrm{GPa}$, it decomposes into a mixture of solid $\mathrm{Fe}_{7} \mathrm{C}_{3}$ and hcp-Fe at above $145 \mathrm{GPa}$ upon laser heating and transforms into $\mathrm{Fe}-\mathrm{C}$ liquid and solid $\mathrm{Fe}_{7} \mathrm{C}_{3}$ at temperatures of above $3400 \mathrm{~K}$ [13]. Moreover, the high Poisson's ratio of $\mathrm{Fe}_{7} \mathrm{C}_{3}$ at high pressures [2] indicates that the presence of carbon may significantly affect the elastic properties of iron. This corroborates the Preliminary Reference Earth Model (PREM) [14], which suggests the material of Earth's inner core also has a high Poisson's ratio.

Contrary to the binary iron-carbon system, the $\mathrm{Fe}-\mathrm{Ni}-\mathrm{C}$, and $\mathrm{Ni}-\mathrm{C}$ systems at high PT conditions are still poorly understood. Nickel can strongly modify the physical properties of pure Fe at elevated pressures and temperatures. Recent studies have shown that Ni 
alloying on Fe does not affect the melting temperature of Fe up to $100 \mathrm{GPa}$; however, it modifies its phase boundary by shifting the hcp/fcc/liquid triple point to the higher pressure-temperature region [6]. For example, for Fe-20 wt.\% Ni alloy the triple point was found to be at 170(20) GPa and 4000(400) K [6] as compared to 100(10) GPa and 3500(200) K for pure Fe [15]. Pressure-induced Invar effect in Fe-Ni alloys was reported by Dubrovinsky et al. [16]. The thermal expansion of the alloys $\mathrm{Fe}_{0.55} \mathrm{Ni}_{0.45}$ and $\mathrm{Fe}_{0.20} \mathrm{Ni}_{0.80}$ was found to be extremely low in the temperature interval of $291 \mathrm{~K}$ to $500 \mathrm{~K}$ at pressures of 7.7 and 12.6 GPa, correspondingly [16]. It was also proven that alloys of Fe with Ni have significantly higher strength in comparison with pure $\mathrm{Fe}$ [17]. The mineral cohenite, (Fe, $\mathrm{Ni})_{3} \mathrm{C}$, which is isostructural to $\mathrm{Fe}_{3} \mathrm{C}$, was found in iron meteorites [18] and predicted to be stable at high pressures [19]. However, a pure-Ni cementite-type phase $\left(\mathrm{Ni}_{3} \mathrm{C}\right)$ has never been reported before.

Here, we report the synthesis and EOS of a novel high-pressure phase of nickel carbide $\left(\mathrm{Ni}_{3} \mathrm{C}\right)$ in a laser-heated diamond anvil cell (LHDAC) at 184(5) GPa and 3500(200) K which was solved and refined using in-situ synchrotron single-crystal X-ray diffraction.

\section{Materials and Methods}

In our experiments, we used the BX90-type large X-ray aperture Diamond Anvil Cell (DAC) equipped with Boehler-Almax type diamonds with $80 \mu \mathrm{m}$ culet diameter. To form the sample chamber, a rhenium gasket was preindented to $\sim 20 \mu \mathrm{m}$ thickness and a hole of $40 \mu \mathrm{m}$ in diameter was drilled at the center of the indentation. A nickel powder was clamped between two thin layers of LiF inside the DAC's sample chamber. LiF played a role of a pressure transmitting and thermal insulating medium in order to decrease temperature gradients in the sample during laser heating [20]. The pressure was determined using the equations of states (EOSes) of $\mathrm{Ni}$ [21] and monitored additionally using Raman signal from the diamond anvils [22].

The laser-heating $(\mathrm{LH})$ of the samples was performed using in house laser heating setup [23]. The double-sided LH system is equipped with two YAG lasers (1064 nm central wavelength) and the IsoPlane SCT 320 spectrometer with a $1024 \times 2560$ PI-MAX 4 camera for the collection of thermal emission spectra from the heated spot. Temperatures were determined by fitting of thermal emission spectra of the sample to the grey body approximation of Planck's radiation function in a given wavelength range (570-830 nm).

High-pressure single-crystal and powder X-ray diffraction (SCXRD) experiments were carried out at the extreme conditions beamline P02.2 (DESY, Hamburg, Germany) [24] and material science beamline ID11 (ESRF, Grenoble, France). The following beamline setups were used: At P02.2, $\lambda=0.29 \AA$, the beam size $\sim 2 \times 2 \mu \mathrm{m}^{2}$, a Perkin Elmer XRD 1621 detector; at ID11, $\lambda=0.30996 \AA$, the beam size $\sim 0.5 \times 0.5 \mu \mathrm{m}^{2}$, a Frelon4M detector. Single-crystal XRD data were collected during rotation of the DAC around the vertical $\omega$-axis in a range $\pm 35^{\circ}$. The diffraction images were collected with an exposure time of $5 \mathrm{~s}$ per frame with an angular step $\Delta \omega=0.5^{\circ}$.

To analyze the SCXRD data we used the CrysAlisPro software [25]. The analysis procedure includes the peak search, finding reflections belonging to a unique singlecrystal domain, indexing, and data integration. The crystal structures were solved using ShelXT [26] structure solution program and refined with the JANA 2006 software [27].

Powder diffraction measurements were performed either without or upon continuous sample rotation about the $\omega$ axis of a diffractometer in the range of $\pm 20^{\circ}$. The images were integrated into powder patterns with Dioptas software [28] and analyzed with Le Bail fitting technique using TOPAS 4.2. The parameters of the equation of state were obtained by fitting the pressure-volume data using EoSFit7-GUI software [29].

\section{Results and Discussion}

Sample of Ni powder was pressurized in LiF pressure-transmitting medium up to 184(5) GPa and laser-heated up to 3500 (200) K by scanning of the Ni sample with a laser 
beam. A direct reaction between $\mathrm{Ni}$ and carbon from the diamond anvil resulted in the synthesis of a new compound indexed as orthorhombic (Figure 1).

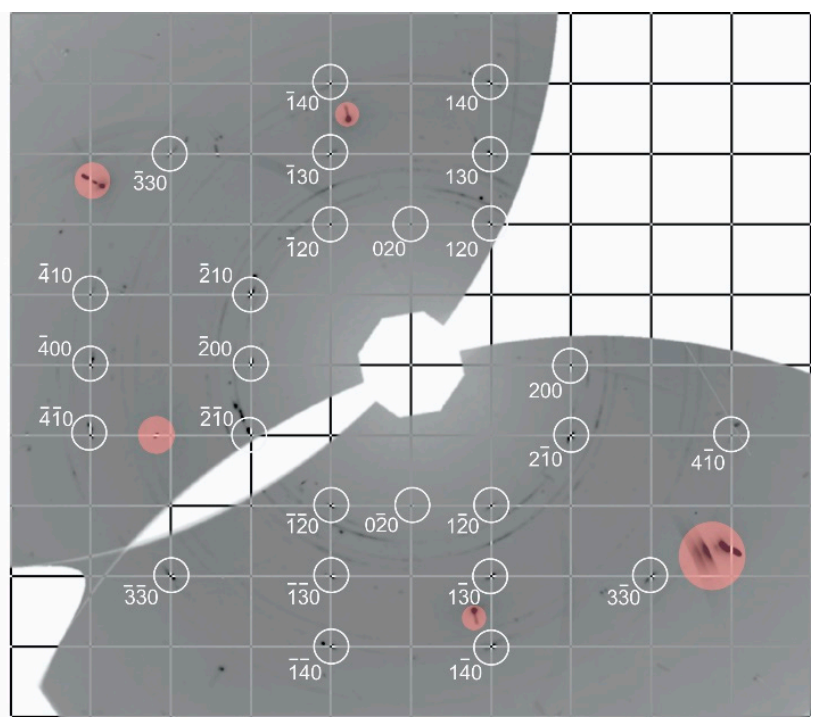

Figure 1. Reconstructed reciprocal lattice planes of orthorhombic $\mathrm{Ni}_{3} \mathrm{C}$ compound with the cementitetype structure. Reflections highlighted by red circles correspond to diamond, diffraction rings correspond to $\mathrm{Re}, \mathrm{Ni}$, and $\mathrm{LiF}$.

In order to localize the point of interest, high-resolution two-dimensional X-ray diffraction mapping $(40 \times 40$ steps of $1 \mu \mathrm{m}$ each) through the whole sample was realized at the ID11 beamline at the ESRF (Figure 2).

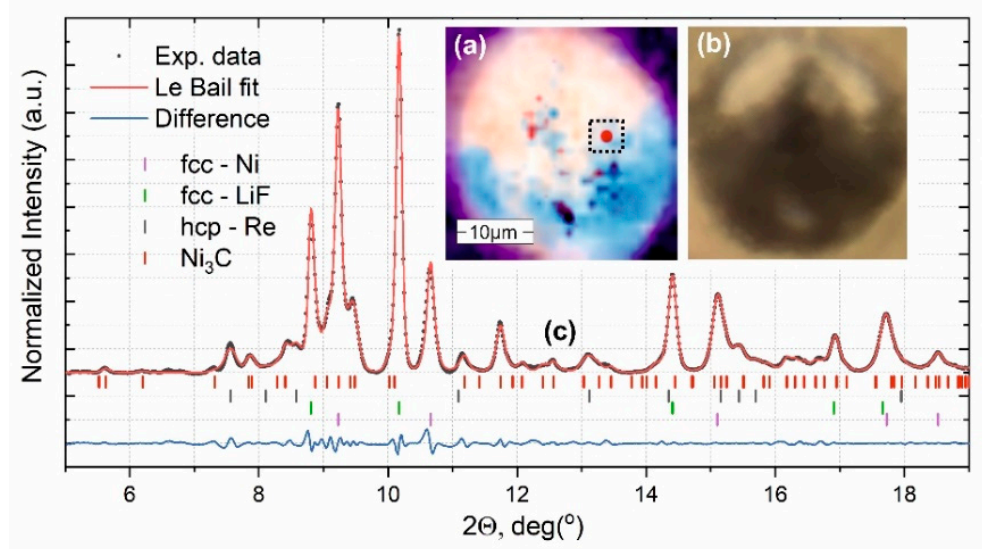

Figure 2. (a) Two-dimensional X-Ray diffraction mapping of the sample chamber. The color map allowing to distinguish between the present phases. The intensity of the colors is proportional to the intensity of particular reflections: the dark purple region beyond the pressure chamber corresponds to the (100) and (101) reflections of the Re gasket; the blue region-the (200) reflection of the Ni; The orange region - the (111) reflection of $\mathrm{LiF} ;(020)$ and (301) reflection of $\mathrm{Ni}_{3} \mathrm{C}$ for the red region. (b) A comparison view of the sample chamber under an optical microscope. (c) Powder diffraction pattern the temperature quenched sample at 184(5) GPa at the position highlighted by a black dotted square on the XRD color map.

The reaction products consist of numerous single-crystalline grains that were identified using synchrotron single-crystal XRD. For one of such grains (one crystallite domain), we were able to collect 182 independent reflections and reduce the data with $R_{\text {int }}=7.3 \%$ at 184(5) GPa. The structure solution and refinement (final $R_{1}=6.4 \%$, see Table 1 ) revealed the cementite-type orthorhombic structure (space group Pnma, \#62; $a=4.520(3) \AA, b=5.8014$ (17) 
$\AA, c=4.009(4) \AA$ at $184(5) \mathrm{GPa}$ ) and the $\mathrm{Ni}_{3} \mathrm{C}$ chemical composition (Table 1, Supplementary Material, Crystallographic Information File: $\mathrm{Ni}_{3} \mathrm{C} \_184 \mathrm{GPa}$.cif).

Table 1. Crystallographic data for the $\mathrm{Ni}_{3} \mathrm{C}$ at 184(5) GPa and $293 \mathrm{~K}$.

\begin{tabular}{|c|c|}
\hline Chemical Formula & $\mathrm{Ni}_{3} \mathrm{C}$ \\
\hline Crystal system & Orthorhombic \\
\hline Space group & Pnma \\
\hline Pressure $(\mathrm{GPa})$ & $184(5)$ \\
\hline Temperature (K) & 293 \\
\hline$a(\AA)$ & $4.520(3)$ \\
\hline$b(\AA)$ & $5.8014(17)$ \\
\hline$c(\AA)$ & $4.009(4)$ \\
\hline$V\left(\AA^{3}\right)$ & 105.12(13) \\
\hline Z & 4 \\
\hline $\operatorname{Density}\left(\mathrm{g} \cdot \mathrm{cm}^{-3}\right)$ & 11.884 \\
\hline Radiation type & synchrotron, $\lambda=0.2895 \AA$ \\
\hline Diffractometer & P02.2@DESY \\
\hline $\begin{array}{l}\text { No. of measured, Independent and observed } \\
\qquad[\mathrm{I}>3 \sigma(\mathrm{I})] \text { reflections }\end{array}$ & $366,182,83$ \\
\hline Rint & $7.3 \%$ \\
\hline Refinement method & Full matrix least-squares on $\mathrm{F}$ \\
\hline $\mathrm{R}[\mathrm{F}>3 \sigma(\mathrm{F})], \mathrm{wR}(\mathrm{F}), \mathrm{S}$ & $6.43,8.42,1.43$ \\
\hline No. of parameters & 19 \\
\hline$\Delta \rho \max , \Delta \rho \min \left(\mathrm{e} \cdot \AA^{-3}\right)$ & $3.09,-3.51$ \\
\hline
\end{tabular}

The structure can be described as built of distorted trigonal prisms formed by six nickel atoms coordinating a $\mathrm{C}$ atom (Figure 3 ). The Ni-C distances in the prism vary from 1.760 (19) to 1.830(16) $\AA$ at 184(5) GPa. The trigonal prisms, interconnected through sharing edges and corners, form layers parallel to the ac plane stacking along the $b$ direction. The previously observed trigonal $\mathrm{Ni}_{3} \mathrm{C}$ ( $\mathrm{R}-3 \mathrm{c}$ space group), which is a product of the thermal decomposition of $\mathrm{Ni}$ succinate [30] is built of $\mathrm{CNi}_{6}$ octahedra with an average $\mathrm{Ni}-\mathrm{C}$ distance of $1.86 \AA$. Thus, the average Ni-C distance depends on the coordination of $\mathrm{C}$ atoms. Our data suggest that at ambient pressure the average $\mathrm{Ni}-\mathrm{C}$ distance in $\mathrm{CNi}_{6}$ trigonal prisms should be significantly lager compared to that inCNi ${ }_{6}$ octahedra.

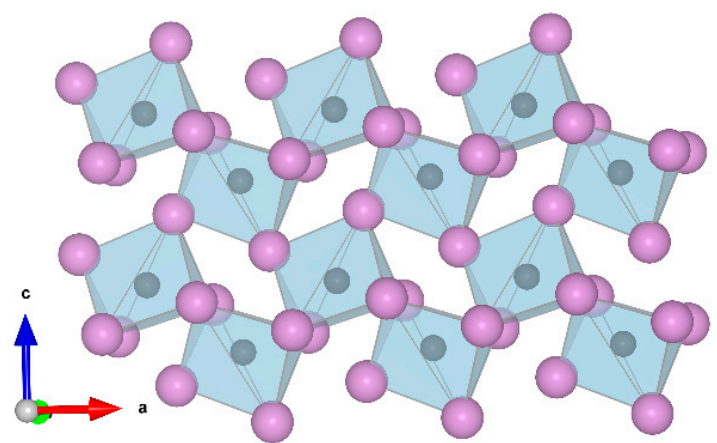

Figure 3. Crystal structure of the cementite type $\mathrm{Ni}_{3} \mathrm{C}$ at 184(5) GPa and room temperature. Purple and black spheres designate nickel and carbon atoms, correspondingly.

The $\mathrm{Ni}_{3} \mathrm{C}$ sample was studied on a stepwise decompression. SCXRD data were collected at seven pressure points down to 84(2) GPa. Below 84(2) GPa no diffraction pattern from $\mathrm{Ni}_{3} \mathrm{C}$ was observed; however, the reason remained unclear. That means the question as to if the quality of the sample deteriorated or the phase decomposed or amorphized stays open. The pressure-volume data (Table 2) of $\mathrm{Ni}_{3} \mathrm{C}$ was fitted to the $3 \mathrm{rd}$ order Birch-Murnaghan (BM3) EOS and gave the following parameters: $\mathrm{V}_{0}=147.7(8) \AA^{3}$; $\mathrm{K}_{0}=157(10) \mathrm{GPa}, \mathrm{K}^{\prime}=7.8(6)$ (Figure 4). 
Table 2. The pressure dependence of the unit cell parameter of $\mathrm{Ni}_{3} \mathrm{C}$. Values in parentheses correspond to experimental uncertainties.

\begin{tabular}{cc}
\hline Pressure, GPa & Volume, $\AA^{3}$ \\
\hline $84(2)$ & $117.1(6)$ \\
$101(2)$ & $114.7(3)$ \\
$123(3)$ & $111.7(4)$ \\
$142(3)$ & $108.9(4)$ \\
$160(4)$ & $107.4(4)$ \\
$170(4)$ & $106.3(3)$ \\
$184(5)$ & $105.1(2)$ \\
\hline
\end{tabular}

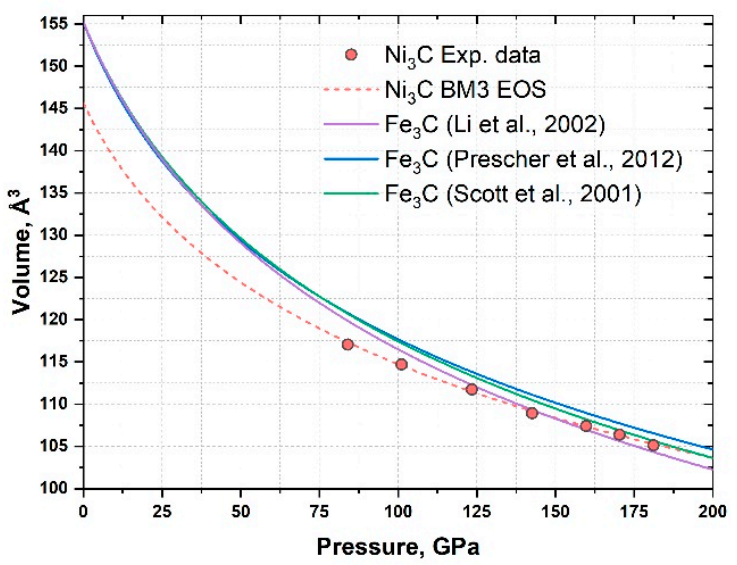

Figure 4. The pressure-volume dependence of $\mathrm{Ni}_{3} \mathrm{C}$. Red dots represent experimental data, the dashed red curve is the BM3 EOS fit $\left(\mathrm{V}_{0}=147.7(8) \AA^{3} ; \mathrm{K}_{0}=157(10) \mathrm{GPa}, \mathrm{K}^{\prime}=7.8(6)\right)$. Solid purple, blue and green lines correspond to the EOSes of $\mathrm{Fe}_{3} \mathrm{C}$ from studies of $\mathrm{Li}$ et al. $\left(\mathrm{K}_{0}=174(6) \mathrm{GPa}\right.$, $\left.\mathrm{K}^{\prime}=4.8(8)\right)$ [31], Prescher et al. $\left(\mathrm{K}_{0}=161(2) \mathrm{GPa}, \mathrm{K}^{\prime}=5.9(2)\right)$ [32] and Scott et al. $\left(\mathrm{K}_{0}=165(4) \mathrm{GPa}\right.$, $\left.\mathrm{K}^{\prime}=5.99(9)\right)[33]$.

Figure 5 demonstrates experimental data on $\mathrm{Ni}_{3} \mathrm{C}$ axial compression. The structure is most compressible along the $\mathrm{b}$ axis, the direction of stacking of the layers of interconnected $\mathrm{CNi}_{6}$ trigonal prisms. Compared to the predicted compressional behavior ofFe ${ }_{3} \mathrm{C}$ in the same pressure region [34], $\mathrm{Ni}_{3} \mathrm{C}$ is highly anisotropic.

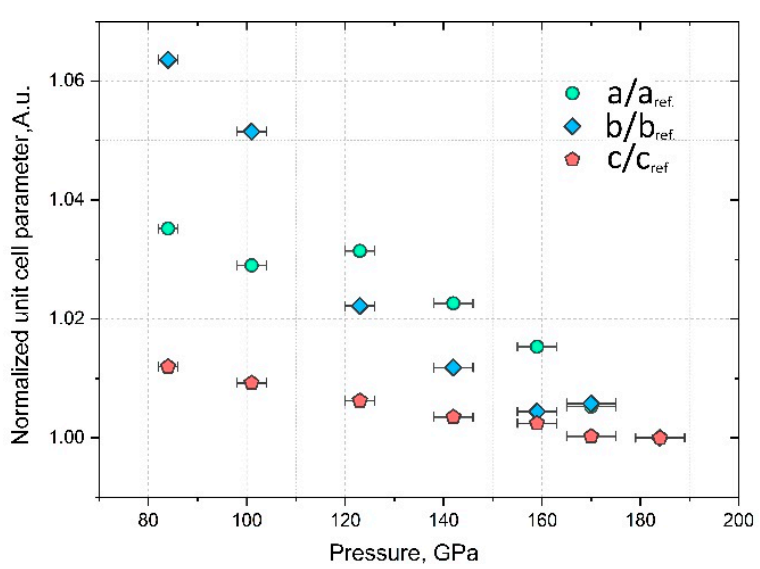

Figure 5. The pressure dependence of the normalized unit cell parameters of $\mathrm{Ni}_{3} \mathrm{C}$ at $300 \mathrm{~K}$.

Based on obtained data, we calculated the bulk sound velocity for $\mathrm{Ni}_{3} \mathrm{C}$ as a function of pressure at $293 \mathrm{~K}$ and compared it with those known for $\mathrm{Fe}, \mathrm{Ni}$, and possible carbon- 
bearing components of Earth's core $\left(\mathrm{Fe}_{3} \mathrm{C}\right.$ and $\left.\mathrm{Fe}_{7} \mathrm{C}_{3}\right)$. Figure 6 shows that within the errors $\mathrm{Ni}_{3} \mathrm{C}$ exhibits similar bulk velocities as $\mathrm{Fe}_{3} \mathrm{C}$ and $\mathrm{Fe}_{7} \mathrm{C}_{3}$ at pressures up to $400 \mathrm{GPa}$.

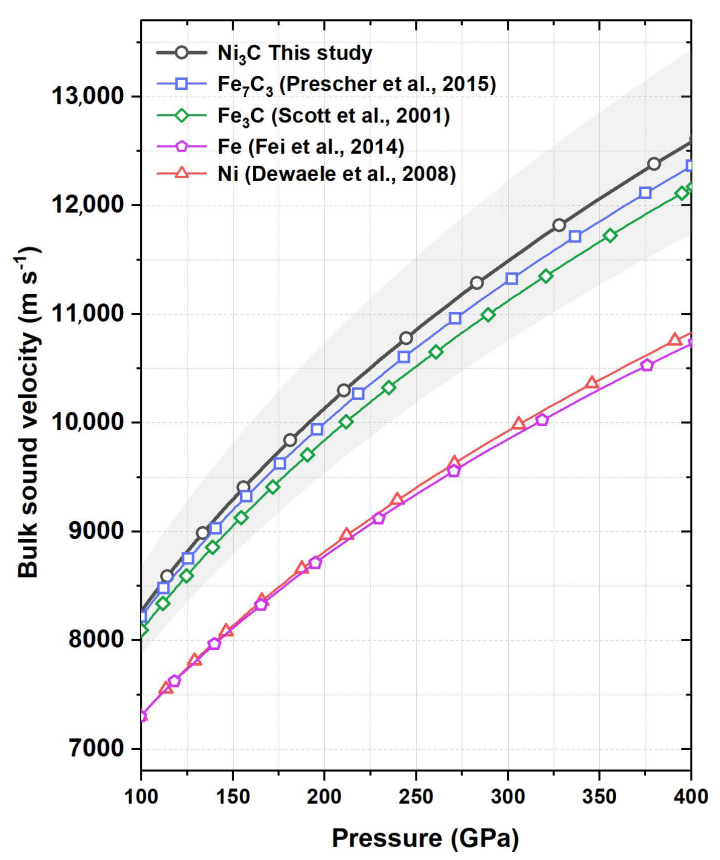

Figure 6. Calculated bulk sound velocity as a function of pressure for $\mathrm{Ni}_{3} \mathrm{C}$ (this study, black solid line with circles); $\mathrm{Fe}_{3} \mathrm{C}$ (green line with diamonds [33]) and $\mathrm{Fe}_{7} \mathrm{C}_{3}$ (blue line with squares [2]); $\mathrm{Ni}$ (red line with triangles [21]); Fe (purple line with pentagons [35]) at $293 \mathrm{~K}$.

Thereby, the presence of $\mathrm{Ni}$ in the alloy likely should not affect the elastic properties of the Fe-Ni-C system at high pressure but potentially can change the carbon distribution. Due to the stability of $\mathrm{Ni}_{3} \mathrm{C}$ at conditions of Earth's outer core, it may be considered as one of the likely candidates to carbon-bearing phases in the core along with $\mathrm{Fe}_{7} \mathrm{C}_{3}$.

\section{Conclusions}

In the presented work, we have synthesized a nickel carbide yet unknown at ambient conditions. It was shown that Ni reacts with carbon at high-pressure and high-temperature conditions that result in the formation of an orthorhombic Ni3C compound (space group Pnma, $a=4.520(3) \AA, b=5.8014(17) \AA, c=4.009$ (4) $\AA$ at 84(5) GPa) with the cementite-type structure revealed using synchrotron single-crystal X-ray diffraction. The $\mathrm{Ni}_{3} \mathrm{C}$ was studied on decompression down to 84(2) GPa. We have shown that in the pressure range 84(2)185(5) $\mathrm{GPa}, \mathrm{Ni}_{3} \mathrm{C}$ is less compressible than cementite $\left(\mathrm{Fe}_{3} \mathrm{C}\right)$; the calculated bulk sound velocities are similar to those known for $\mathrm{Fe}_{3} \mathrm{C}$ and $\mathrm{Fe}_{7} \mathrm{C}_{3}$ at pressures up to $400 \mathrm{GPa}$ and

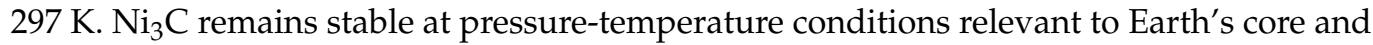
thus can be considered as one of the likely candidates to carbon-bearing phases in the core along with $\mathrm{Fe}_{7} \mathrm{C}_{3}$.

Supplementary Materials: The following are available online at https:/ /www.mdpi.com/article/ 10.3390/min11050516/s1, Crystallographic information file of $\mathrm{Ni}_{3} \mathrm{C}$ at 184(5) GPa.

Author Contributions: Conceptualization, T.F., L.D. and N.D.; methodology, T.F. and S.K.; validation, T.F. and S.K.; formal analysis, T.F.; investigation, T.F., S.K., K.G., P.S.; data curation, T.F.; writingoriginal draft preparation, T.F.; writing-review and editing, N.D. and L.D.; visualization, T.F.; supervision, N.D. and L.D.; project administration, T.F. and L.D.; funding acquisition, N.D. and L.D. All authors have read and agreed to the published version of the manuscript.

Funding: N.D. and L.D. thank the Federal Ministry of Education and Research, Germany (BMBF, grant No. 05K19WC1) and the Deutsche Forschungsgemeinschaft (DFG projects DU 954-11/1, DU 
393-9/2, and DU 393-13/1) for financial support. N.D. thanks the Swedish Government Strategic Research Area in Materials Science on Functional Materials at Linköping University (Faculty Grant SFO-Mat-LiU No. 2009 00971).

Institutional Review Board Statement: Not applicable.

Informed Consent Statement: Not applicable.

Data Availability Statement: The data that support the findings of this study are available from the corresponding author upon reasonable request.

Acknowledgments: We acknowledge DESY (Hamburg, Germany), a member of the Helmholtz Association HGF, for the provision of experimental facilities, photon beamline P02.2 (Petra III).

Conflicts of Interest: The authors declare no conflict of interest.

\section{References}

1. Birch, F. Elasticity and constitution of the Earth's interior. J. Geophys. Res. 1952, 57, 227-286. [CrossRef]

2. Prescher, C.; Dubrovinsky, L.; Bykova, E.; Kupenko, I.; Glazyrin, K.; Kantor, A.; McCammon, C.; Mookherjee, M.; Nakajima, Y.; Miyajima, N.; et al. High Poisson's ratio of Earth's inner core explained by carbon alloying. Nat. Geosci. 2015, 8, 220-223. [CrossRef]

3. Litasov, K.D.; Shatskiy, A.F. Composition of the Earth's core: A review. Russ. Geol. Geophys. 2016, 57, 22-46. [CrossRef]

4. McDonough, W.F. Compositional Model for the Earth's Core. In Treatise on Geochemistry; Elsevier: Amsterdam, The Netherlands, 2003; pp. 547-568.

5. Wood, B.J. Carbon in the core. Earth Planet. Sci. Lett. 1993, 117, 593-607. [CrossRef]

6. Torchio, R.; Boccato, S.; Miozzi, F.; Rosa, A.D.; Ishimatsu, N.; Kantor, I.; Sévelin-Radiguet, N.; Briggs, R.; Meneghini, C.; Irifune, T.; et al. Melting Curve and Phase Relations of Fe-Ni Alloys: Implications for the Earth's Core Composition. Geophys. Res. Lett. 2020, 47, e2020GL088169. [CrossRef]

7. Poirier, J.-P. Light elements in the Earth's outer core: A critical review. Phys. Earth Planet. Inter. 1994, 85, 319-337. [CrossRef]

8. Bashir, N.; Beckett, J.R.; Hutcheon, I.D.; Stolper, E.M. Carbon in the Metal of Iron Meteorites. In Proceedings of the Lunar and Planetary Science Conference, Houston, TX, USA, 18-22 March 1996; Volume 27, p. 63.

9. Hirayama, Y.; Fujii, T.; Kurita, K. The melting relation of the system, iron and carbon at high pressure and its bearing on the early stage of the Earth. Geophys. Res. Lett. 1993, 20, 2095-2098. [CrossRef]

10. Lord, O.T.; Walter, M.J.; Dasgupta, R.; Walker, D.; Clark, S.M. Melting in the Fe-C system to 70 GPa. Earth Planet. Sci. Lett. 2009, 284, 157-167. [CrossRef]

11. Nakajima, Y.; Takahashi, E.; Suzuki, T.; Funakoshi, K. “Carbon in the core” revisited. Phys. Earth Planet. Inter. 2009, 174, $202-211$. [CrossRef]

12. Chen, B.; Li, Z.; Zhang, D.; Liu, J.; Hu, M.Y.; Zhao, J.; Bi, W.; Alp, E.E.; Xiao, Y.; Chow, P.; et al. Hidden carbon in Earth's inner core revealed by shear softening in dense $\mathrm{Fe}_{7} \mathrm{C}_{3}$. Proc. Natl. Acad. Sci. USA 2014, 111, 17755-17758. [CrossRef]

13. Liu, J.; Lin, J.-F.; Prakapenka, V.B.; Prescher, C.; Yoshino, T. Phase relations of $\mathrm{Fe}_{3} \mathrm{C}$ and $\mathrm{Fe}_{7} \mathrm{C}_{3}$ up to $185 \mathrm{GPa}$ and $5200 \mathrm{~K}$ : Implication for the stability of iron carbide in the Earth's core. Geophys. Res. Lett. 2016, 43, 12415-12422. [CrossRef]

14. Dziewonski, A.M.; Anderson, D.L. Preliminary reference Earth model. Phys. Earth Planet. Inter. 1981, 25, 297-356. [CrossRef]

15. Morard, G.; Boccato, S.; Rosa, A.D.; Anzellini, S.; Miozzi, F.; Henry, L.; Garbarino, G.; Mezouar, M.; Harmand, M.; Guyot, F.; et al. Solving Controversies on the Iron Phase Diagram Under High Pressure. Geophys. Res. Lett. 2018, 45, 11-074. [CrossRef]

16. Dubrovinsky, L.; Dubrovinskaia, N.; Abrikosov, I.A.; Vennström, M.; Westman, F.; Carlson, S.; van Schilfgaarde, M.; Johansson, B. Pressure-Induced Invar Effect in Fe-Ni Alloys. Phys. Rev. Lett. 2001, 86, 4851-4854. [CrossRef] [PubMed]

17. Reagan, M.M.; Gleason, A.E.; Liu, J.; Krawczynski, M.J.; Van Orman, J.A.; Mao, W.L. The effect of nickel on the strength of iron nickel alloys: Implications for the Earth's inner core. Phys. Earth Planet. Inter. 2018, 283, 43-47. [CrossRef]

18. Brett, R. Cohenite in Meteorites: A Proposed Origin. Science 1966, 153, 60-62. [CrossRef]

19. Ringwood, A.E. Cohenite as a pressure indicator in iron meteorites. Geochim. Cosmochim. Acta 1960, 20, 155-158. [CrossRef]

20. Dong, H.; Dorfman, S.M.; Holl, C.M.; Meng, Y.; Prakapenka, V.B.; He, D.; Duffy, T.S. Compression of lithium fluoride to 92 GPa. High Press. Res. 2014, 34, 39-48. [CrossRef]

21. Dewaele, A.; Torrent, M.; Loubeyre, P.; Mezouar, M. Compression curves of transition metals in the Mbar range: Experiments and projector augmented-wave calculations. Phys. Rev. B 2008, 78, 104102. [CrossRef]

22. Akahama, Y.; Kawamura, H. Pressure calibration of diamond anvil Raman gauge to 310GPa. J. Appl. Phys. 2006, 100, 043516. [CrossRef]

23. Fedotenko, T.; Dubrovinsky, L.; Aprilis, G.; Koemets, E.; Snigirev, A.; Snigireva, I.; Barannikov, A.; Ershov, P.; Cova, F.; Hanfland, M.; et al. Laser heating setup for diamond anvil cells for in situ synchrotron and in house high and ultra-high pressure studies. Rev. Sci. Instrum. 2019, 90, 104501. [CrossRef] 
24. Liermann, H.-P.; Konôpková, Z.; Morgenroth, W.; Glazyrin, K.; Bednarčik, J.; McBride, E.E.; Petitgirard, S.; Delitz, J.T.; Wendt, M.; Bican, Y.; et al. The Extreme Conditions Beamline P02.2 and the Extreme Conditions Science Infrastructure at PETRA III. J. Synchrotron Radiat. 2015, 22, 908-924. [CrossRef]

25. CrysAlis Pro (v. 171.39.46). Available online: https://www.rigaku.com/products/smc/crysalis (accessed on 3 January 2020).

26. Sheldrick, G.M. SHELXT-Integrated space-group and crystal-structure determination. Acta Crystallogr. Sect. A Found. Adv. 2015, 71, 3-8. [CrossRef] [PubMed]

27. Petř́ček, V.; Dušek, M.; Plášil, J. Crystallographic computing system Jana2006: Solution and refinement of twinned structures. Zeitschrift für Krist. Cryst. Mater. 2016, 231, 583-599. [CrossRef]

28. Prescher, C.; Prakapenka, V.B. DIOPTAS: A program for reduction of two-dimensional X-ray diffraction data and data exploration. High Press. Res. 2015, 35, 223-230. [CrossRef]

29. Gonzalez-Platas, J.; Alvaro, M.; Nestola, F.; Angel, R. EosFit7-GUI: A new graphical user interface for equation of state calculations, analyses and teaching. J. Appl. Crystallogr. 2016, 49, 1377-1382. [CrossRef]

30. Huba, Z.J.; Carpenter, E.E. Monitoring the formation of carbide crystal phases during the thermal decomposition of $3 \mathrm{~d}$ transition metal dicarboxylate complexes. Dalt. Trans. 2014, 43, 12236-12242. [CrossRef]

31. Li, J.; Mao, H.K.; Fei, Y.; Gregoryanz, E.; Eremets, M.; Zha, C.S. Compression of Fe 3 C to 30 GPa at room temperature. Phys. Chem. Miner. 2002, 29, 166-169. [CrossRef]

32. Prescher, C.; Dubrovinsky, L.; McCammon, C.; Glazyrin, K.; Nakajima, Y.; Kantor, A.; Merlini, M.; Hanfland, M. Structurally hidden magnetic transitions in $\mathrm{Fe}_{3} \mathrm{C}$ at high pressures. Phys. Rev. B 2012, 85, 140402. [CrossRef]

33. Scott, H.P.; Williams, Q.; Knittle, E. Stability and equation of state of Fe 3 C to 73 GPa: Implications for carbon in the Earth's core. Geophys. Res. Lett. 2001, 28, 1875-1878. [CrossRef]

34. Mookherjee, M. Elasticity and anisotropy of $\mathrm{Fe}_{3} \mathrm{C}$ at high pressures. Am. Miner. 2011, 96, 1530-1536. [CrossRef]

35. Fei, Y.; Murphy, C.; Shibazaki, Y.; Shahar, A.; Huang, H. Thermal equation of state of hcp-iron: Constraint on the density deficit of Earth's solid inner core. Geophys. Res. Lett. 2016, 43, 6837-6843. [CrossRef] 